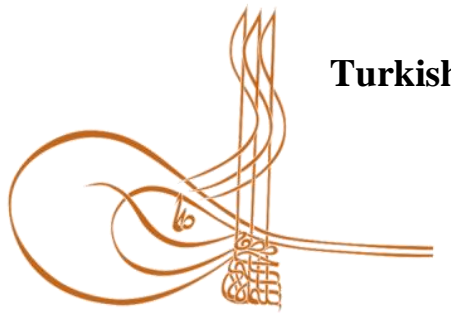

www.turkishstudies.net/appliedsciences
eISSN: 2667-5633

Research Article / Araştırma Makalesi

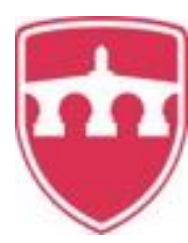

INTERNATIONAL

BALKAN

UNIVERSITY

Sponsored by IBU

\title{
Firmaların Endüstri 4.0 Olgunluk Düzeylerinin Tespitine Yönelik Bir Araştırma: Sivas İli Örneği ${ }^{*}$
}

\author{
A Research on Determination of the Companies' Industrial 4.0 Maturity Levels: Case of Sivas \\ Province
}

\author{
Ali Rıza İnce ${ }^{* *}$ - Mehmet Zahit Şimşek ${ }^{* * *}$
}

\begin{abstract}
The firms, that understand the importance of Industry 4.0, which has the potential to change the competitive balances to a large extent, have attempted to shape their strategies within the framework of the new industrial revolution, make investments, and improve their practices. The first thing to do in terms of companies and sectors is the determination of the levels of preparation for this revolution. Only after determining the maturity levels, road maps can be prepared, resources can be allocated to this issue and implemented. This study was carried out in order to have an idea about the Industry 4.0 maturity levels of the companies, In particular, in order to determine the Industry 4.0 maturity levels and weaknesses and strengths of the companies in Sivas. In the study, the maturity model consisting of 6 dimensions, 37 sub-dimensions and 4 evaluation levels named "An Industry 4.0 Readiness Assessment Tool" was used. The application of the model, which was reorganized and turned into a questionnaire, was applied to manufacturing companies in the Sivas organized industrial zone. Descriptive statistics used in the evaluation of the original maturity model were used in the data obtained. The maturity model dimensions and dimensions were evaluated according to the demographic data of the companies and the findings were interpreted. Considering all the dimensions in the maturity model, it was found that the firms participating in the study were at a level below the middle level in terms of Industry 4.0 preparation. It can be said that companies are the most prepared in terms of dimension of Products and Services, and they are the least prepared in terms of dimensions of Production and Operations, Strategy and Organization.
\end{abstract}

\section{Structured Abstract: $\square$ Introduction and Purpose of Study}

\footnotetext{
* Bu çalışma Mehmet Zahid ŞİMŞEK'in, Ocak 2020'de, Cumhuriyet Üniversitesi, Sosyal Bilimler Enstitüsü, Yönetim Bilişim Sistemleri Anabilim Dalı'nda tamamladığı “Endüstri 4.0 Olgunluk Düzeylerinin Tespitine Yönelik Bir Araştırma: Sivas İli Örneği” başlıklı Yüksek Lisans tezinden türetilmiş ve geliştirilmiştir.

** Doç. Dr., Cumhuriyet Üniversitesi, İktisadi ve İdari Bilimler Fakültesi, Yönetim Bilişim Sistemleri Bölümü Assoc.Prof. Dr., Cumhuriyet University, Faculty of Economics and Adminitrative Science 
The social and economic area, where significant changes and transformations have taken place since the 18th century, is perhaps experiencing a greater breakthrough from the first three industrial revolution in the fourth industrial revolution. The fourth industrial revolution has the potential to make significant advances in indicators such as growth, productivity, employment, diversity, and quality by creating radical changes in social, economic, cultural fields, and especially in the field of production.

There are a number of technologies that made this revolution possible, which are called Industry 4.0 components. These components are: Cyber Physical Systems, Internet of Things, Big Data and Analytics, Cloud Computing, Horizontal and Vertical Integration, Autonomous Robots, 3D Printing, Augmented Reality and Cyber Security.

The aim of this study is to measure the maturity levels of the companies about Industry 4.0, to reveal the weak and strong aspects of this preparations and to make an assessment for the general, in Sivas Province, using a detailed maturity model. It is another purpose of the study to give information about which subjects should focus on in order for companies not to lose their competitive advantage in the future.

\section{$\square$ Theoretical Framework}

There are models developed to measure the level of preparation of companies about industry 4.0, which are called maturity models. Although there are many models that have been developed recently, the model named 'An Industry 4.0 Readiness Assessment Tool', which was created by the University of Warwick academics in collaboration with various companies, was used in this study.

The purpose of this Model is to assess Industry 4.0 preparation and to understand future requirements. The model consists of 4 evaluation levels, 37 sub-dimensions and 6 dimensions such as Products and Services, Production and Operations, Strategy and Organization, Supply Chain, Business Model, Legal Issues. The maturity model consists of four evaluation levels: beginner, intermediate, expert and experienced.

\section{$\square$ Research Universe, Sample and Method}

In the research, it was tried to reach all 157 producing firms active in different sectors in Sivas organized industrial zone, but the work could only be carried out with 50 firms. The maturity model was rearranged in accordance with the survey technique and the survey was carried out between 30 May and 25 June 2019. The survey was carried out in the form of face-to-face interviews with the managers of the enterprises, factory managers or engineers directed by them.

\section{$\square$ Result}

The firms, that understand the importance of Industry 4.0, which has the potential to change the competitive balances of all sizes, have taken action to shape their strategies within the framework of the new industrial revolution, to make investments and to improve their practices.

Industry 4.0 is not just a change that firms should take into account, but a revolution that every segment from individuals to social level, from firms to sectors and economies should be prepared. The first thing to do in terms of companies and sectors is the determination of the levels of preparation for this revolution. Only after determining the maturity levels, road maps can be prepared, resources can be allocated to this issue and implemented.

This study was carried out in order to have an idea about the Industry 4.0 preparation levels of the firms, and to determine the Industry 4.0 maturity levels and weaknesses and strengths of the firms producing in Sivas.

It has been determined that the companies participating in the study are in the Production and Operations, Strategy and Organization, Business Model, Legal Matters dimensions, and between the intermediate and experienced levels in the dimensions of the Product and Services and Supply Chain.

It has been determined that the companies participating in the study are between the beginner and intermediate level in the dimensions of Production and Operations, Strategy and Organization, Business Model, Legal Issues and are between the mid-level and the experienced level in the dimensions of the Product and Services and Supply Chain. 
When all dimensions are taken into consideration in the maturity model, it can be said that the companies participating in the study are generally at a level below the middle level in the preparation of Industry 4.0, and that the companies are the most prepared in the Product and Services dimension, and the least in the Production and Operations dimension, and the Strategy and Organization dimension.

Considering the main dimensions of the maturity model and the demographic characteristics of the companies, it can be said that those who are active in the metal industry, those who have been operating for 20 years or more, large-scale and internationally operating companies are more prepared about Industry 4.0 than other companies.

According to these results, it is revealed that the companies participating in the study are generally at a low level regarding Industry 4.0 maturity. The reasons for this situation are that the firms still do not want to abandon traditional production methods, have technically insufficient equipment and employees (such as employees with digital skills), are not susceptible to Industry 4.0 in terms of organizational culture, and do not adopt new business models and do not invest enough in this regard. In addition, it is another shortcoming for companies that the leader team thinks of the concept of Industry 4.0 as a temporary trend and a long and costly process that does not bring profit in a short time.

Some studies can be done in order to eliminate the deficiencies in Industry 4.0 and to make the companies reach an important level about Industry 4.0 maturity. These may be to raise awareness about Industry 4.0, to develop infrastructure and preparations, to provide technical support in areas such as Information Technologies through the state, to provide investment and incentives, and to ensure that companies cooperate on a national platform.

Keywords: Industrial Revolutions, Industry 4.0, Maturity Models, Manufacturing Firms

Öz: Rekabet dengelerini büyük ölçüde değiştirebilme potansiyeline sahip Endüstri 4.0’’n önemini kavrayan firmalar, stratejilerini yeni sanayi devrimi çerçevesinde şekillendirme, yatırımlarda bulunma, uygulamalarını ilerletme gayreti içine girmişlerdir. Firma ve sektörler açısından yapılması gereken ilk iş bu devrime hazırlık düzeylerinin tespitidir. Ancak hazırlık düzeylerinin tespitinden sonra, yol haritaları hazırlanabilir, kaynaklar tahsis edilebilir ve uygulamaya geçilebilir. Genel olarak firmaların Endüstri 4.0 hazırlık düzeyleri hakkında fikir sahibi olmak, özellikle de Sivas ilindeki imalat firmalarının Endüstri 4.0 olgunluk düzeylerini ve bu konudaki zayıf ve güçlü yönlerini tespit edebilmek amacıyla bu çalışma gerçekleştirilmiştir. Çalışmada "Endüstri 4.0 Hazırlık Değerlendirme Aracı" isimli 6 boyut, 37 alt boyut ve 4 değerlendirme seviyesinden oluşan olgunluk modeli kullanılmıştır. Yeniden düzenlenerek ankete dönüştürülen modelin uygulaması, Sivas ili organize sanayi bölgesindeki imalat firmalarına uygulanmıştır. Elde edilen verilere betimleyici istatistikler uygulanarak, olgunluk modeli boyutlarının ve boyutların firmaların demografik verilerine göre değerlendirmeleri yapılmış ve bulgular yorumlanmıştır. Olgunluk modelinde tüm boyutlar göz önüne alındığında, çalışmaya katılan firmaların Endüstri 4.0 hazırlığı konusunda genel anlamda orta seviyenin altında bir düzeyde yer aldıkları; yine firmaların Ürün ve Hizmetler boyutunda en fazla hazırlıklı oldukları; Üretim ve İşlemler ile Strateji ve Organizasyon boyutunda ise en az hazırlıklı oldukları söylenebilir.

Anahtar Kelimeler: Sanayi Devrimleri, Endüstri 4.0, Olgunluk Modelleri, İmalat Firmaları

\section{Giriş}

18. Yüzyıldan itibaren önemli değişim ve dönüşümlerin gerçekleştiği toplumsal ve ekonomik alan belki de ilk üç sanayi devriminden daha büyük bir kırılmayı dördüncü sanayi devriminde yaşamaktadır. Endüstri 4.0 olarak da adlandırılan dördüncü sanayi devrimi, sosyal, ekonomik, kültürel ve özellikle de üretim alanında köklü değişimler meydana getirerek büyüme, verimlilik, istihdam, çeşitlilik, kalite gibi göstergelerde çok önemli ilerlemeler sağlama potansiyeline sahiptir. Endüstri 4.0’’n zaman içerisinde, her ölçekte rekabet dengesini değişstireceği de ön görüler arasına girmiş böylelikle bu denli hayati bir olgu hakkında tedbirlerin alınması, yol haritalarının ve altyapıların hazırlanması güncel konular haline gelmiştir. 
Endüstri 40'1n geçici bir trend, kısa dönemde kâr getirmeyen bir değişim olduğunu ve sanılanın aksine büyük etkiler meydana getirmeyeceğini iddia eden çeşitli yaklaşımların aksine bireyden firmalara, ekonomiden ülkelere kadar geniş bir alana etki eden bu değişime atfedilen önem gittikçe artmaktadır. Endüstri 4.0'1 iş stratejilerine dâhil ederek bu konuda faaliyete geçen çok sayıda firma bulunmaktadır. Bu firmalar, Endüstri 4.0 konusundaki farkındalıklarını artırmak, gerekliliklerini anlamak, zayıf ve güçlü yönlerini öğrenmek ve hangi seviyede olduklarını tespit edebilmek için 'Olgunluk Modelleri' olarak adlandırılan çeşitli araçlara ihtiyaç duymaktadırlar.

$\mathrm{Bu}$ çalışmanın amacı, detaylı bir olgunluk modelini kullanarak, Endüstri 4.0 konusunda Sivas ilinde üretim yapan firmaların hazırlık düzeylerini ölçmek, hazırlık konusundaki zayıf ve güçlü yönlerini ortaya koymak ve geneli için bir değerlendirmede bulunmaktır. Firmaların ilerleyen zamanlarda rekabet üstünlüklerini kaybetmemeleri için hangi konulara ağırlık vermeleri gerektiğini belirlemek de çalışmanın diğer bir amacını teşkil etmektedir.

\section{Sanayi Devrimleri}

I. Sanayi Devrimi, buhar enerjisi ile çalı̧an makinelerin ve üretim tesislerinin devreye girmesiyle 18. Yüzyılın sonlarına doğru ortaya çıkmıştır. Bu devrim, üretimde insan gücünü azaltarak makinelerin üretim süreçlerinde yer almasına ve üretimin fabrikalara taşınmasına sebep olmuştur. II. Sanayi Devrimi, 19. Yüzyılın ortalarına doğru elektriğin sanayide kullanılmasıyla ortaya çıkmıştır. Henry Ford'un otomobil fabrikasında üretim bandı tasarımı, seri üretim imkânı sağlarken, yeni sanayi devriminin ortaya çıkmasına da öncülük etmiştir. Seri üretim ve standart ürüne dayalı düşük maliyetli bu üretim modeli, ikinci sanayi devriminin temel kriterlerini oluşturmuş̧ur. III. Sanayi Devrimi ise ilk kez geliştirilen programlanabilir makineler ile 1970'li yıllardan itibaren kendini hissettirmeye başlamıştır. Bu dönemde elektronik ve BT (Bilişim Teknolojileri) sistemlerinin üretim süreçlerinde otomasyonu gerçekleştirmesi ile üretim teknolojilerinde yeni bir devrim başlamıştır (Swab, 2016).

Endüstri 4.0 kavramı, ilk defa Alman hükümeti tarafindan üniversiteler ve özel şirketlerin işbirliğinde yapılan çalışma ile 2011 Hannover Fuarı'nda öne sürülmüştür (Sung, 2018). Endüstri 4.0, fabrikanın tüm ürün yaşam döngüsüne değer katan ve bir dizi birbirine yakın teknolojiyi bir araya getiren üretim sistemlerinin yeni bir endüstriyel aşamaya gelmesini temsil etmektedir. $\mathrm{Bu}$ yeni endüstriyel aşama, değer zincirindeki tüm faaliyetlerin 'akıllı' yaklaşımlarla birlikte gerçekleştirdiği, bilgi ve iletişim teknolojilerine dayanan ve üretim sistemlerinde insanın yeni sosyo-teknik rolünü barındıran bir özelliğe sahiptir (Frank vd., 2019). Bu devrimin gerçekleşmesini olanaklı kılan bir takım teknolojiler vardır ki bunlar Endüstri 4.0 bileşenleri olarak adlandırılır.

\section{Endüstri 4.0 Bileşenleri}

\section{Siber Fiziksel Sistemler}

Siber fiziksel sistemler, aküatörler ve sensörler gibi cihazlardaki gömülü sistemlerin fiziksel dünyayı algılamak, izlemek ve kontrol etmek için internet ağında birbirine bağlı olduğu coğrafi olarak dağılmış, büyük ölçekli, hayati önem taşıyan ve buna benzer özelliklere sahip olan sistemlerdir (Ding vd., 2018). Siber fiziksel sistemler; sensöri, hesaplama ve ağ teknolojilerini kullanarak siber sistemler ile fiziksel sistemleri etkin bir şekilde bütünleştirebilen sistemler olarak da tanımlanabilmektedir (Alguliyev vd., 2018).

\section{Nesnelerin İnterneti}

Nesnelerin interneti; bilgi ve iletişim teknolojileri yardımıyla fiziksel ve sanal nesneleri birbirine bağlamak suretiyle gelişmiş hizmetler sağlayan küresel bir altyapıdır (ITU, 2012). Akıllı ev otomasyonu alanında, enerji sistemlerinin yönetilmesi ve verimliliğinin sağlanması; sağlık alanında, hastaların fizyolojik verilerinin (nabız, kan şekeri vb.) takibi; tarım ve hayvancılıkta toprağın fiziksel durumunun tespiti, hayvanların fiziksel durumlarının kontrolü (hastalık durumu 
üzerine yapılan tespitler vb.) ve süt verimliliğinin üzerine yapılan çalışmalar, nesnelerin internetinin uygulama alanlarına örnektir.

\section{Büyük Veri ve Analitik}

Büyük veri, sıradan veri tabanı yazılım araçlarının yakalama, depolama, yönetme ve analiz etme yeteneği ile üstesinden gelinemeyecek büyüklükte olan veri kümleridir (Manyika, 2011). Büyük veri; terabaytlar veya petabaytlar olarak ifade edilen büyüklükte, yüksek hızda veri akışı oluşturmakta ve format olarak (yapısal, yarı yapısal veya yapısal olmayan) karmaşık çeşitliliktedir. Aynı zamanda büyük veri, güvenilirlik ve kullanım açısından artı bir değer oluşturan bir veridir. Sağlık sektöründe yan etkisi bulunan ilaçların tespit edilmesi; bankacılık sektöründe çağrı merkezindeki görüşmelerin analizi ve müşteri memnuniyeti; trafik alanında yapılan analizler ile trafik yoğunluğunun belirlenmesi ve 1şık planlamasının yapılması büyük veri ve analitiğin uygulama alanlarından bazılarıdır.

\section{Bulut Bilişim}

Bulut bilişim, en alt düzeyde yönetim ve servis sağlayıcı müdahalesi ile işleyebilen, ağ, sunucu, depolama hizmetleri ve uygulamalar gibi hızla işlem yapılabilen bilişim kaynaklarının paylaşıldığ 1 dijital ortama, gerçek zamanlı erişim olanağı tanıyan bir modeldir (Mell ve Grance, 2011). Bulut bilişim, zamandan ve mekândan bağımsız erişim ve kullanım kolaylı̆g 1 ve bakım süreçleri gibi teknik konularda maliyet tasarrufu sağlamaktadır. Bunların yanında yüksek koruma protokollerinden ötürü güvenli kabul edilmesi de bulut bilişimin avantajları arasındadır.

\section{Yatay ve Dikey Entegrasyon}

Yatay entegrasyon, aynı tedarik zincirinde tedarikçilerden müşterilere kadar olan süreçte yer alan, birden fazla şirketin işbirliği yapmalarına olanak sağlayan bir bütünleşmeyi ifade eder. Dikey entegrasyon ise, bir fabrikada var olan tüm fonksiyonların ve farklı kademedeki kişi, iş ve işlerin birbiri ile olan bağlantısı veya işbirliği olarak ifade edilmektedir (Rüßmann vd., 2015).

\section{Otonom Robotlar}

Otonom robot, yaptığı iş, işlem, ürün ve çevresi hakkında veri toplayan ve kendi kendine karar verebilen robottur. Endüstri 4.0'ın önemli bir getirisi de görevleri akıllıca tamamlayabilen güvenli, esnek, çok yönlü ve işbirlikçi robotlar tarafindan desteklenen otonom üretim yöntemidir. $\mathrm{Bu}$ bağlamda robotların kullanım alanları gittikçe genişlemekte ve çeşitlenmektedir. Otonom robotlar sayesinde çalışma alanını izole etme zorunluluğu olmadan, insanların ortama entegrasyonuyla üretimin daha ekonomik ve verimli hale getirilmesi mümkün olmaktadır. Yakın bir gelecekte Endüstri 4.0'da robotlar ve insanlar iş birliği içinde, birbirine bağl1 görevler üzerinde akıllı sensor, insan-makine arayüzleri kullanarak çalışabileceklerdir (Bahrin vd., 2016).

\section{Katmanlı Üretim - 3 Boyutlu Baskı}

Katmanlı üretim veya 3 boyutlu baskı, bilgisayar destekli tasarım (CAD) tarafindan oluşturulan nesneleri, sanal dünyadan fiziksel dünyaya aktarabilen dijital üretim şeklidir (Shafrenek vd., 2019). Katmanlı imalat yöntemlerinin tıp, uzay ve havacılık, otomotiv, askeri donanım, mimari, kişisel araç-gereç, medikal ve eğitim gibi alanlarda kullanıldığı görülmektedir. Gün geçtikçe kullanım alanı genişleyen bu teknolojinin ilerleyen süreçlerde farklı sektörlerde de kullanılabileceği öngörülmektedir.

\section{Artırılmış Gerçeklik}

Artırılmış gerçeklik, sanal sembollerin dış dünyanın gerçek görüntüsüne bindirildiği bir bilgisayar grafik tekniğidir (Ceruti vd., 2019). Artırılmış gerçeklikte gerçek dünyada karşılaşılan nesneler, gerçek nesneleri daha anlamlı ve çekici hale getirecek şekilde kullanıcılara uyum içeresinde sunulmaktadır (Zhu vd., 2004). Müzelerde sanat eserlerinin üzerinde gerçekleştirilen 
uygulamalarla ziyaretçilerin deneyimlerinin artırılması, sağlık eğitimindeki görselleştirmeler, kullanım alanlarına örnek olarak verilebilir.

\section{Siber Güvenlik}

Siber güvenlik; siber ortamı, siber sistemleri ve kullanıcı hesaplarını korumak için kullanılabilecek önlem, yöntem, eğitim ve teknolojilerin toplamıdır (ITU, 2015). Endüstri 4.0 bünyesinde; sistem ağları, donanımlar, yazılımlar gibi birçok teknolojik cihazı barındırmaktadır. $\mathrm{Bu}$ unsurlar endüstriyel, kişisel ve kurumsal anlamda kritik bilgiler üretmekte ve içermektedir. $\mathrm{Bu}$ kritik sistem ve altyapıların, kötü niyetli siber saldırılara karşı cazip hale gelmesi kaçınılmazdır ve bu nedenle siber güvenlik, Endüstri 4.0 için çok önemli bir gerekliliktir.

\section{Endüstri 4.0 Olgunluk Modelleri}

Olgunluk modelleri, örgütsel yeteneklerin geliştirilmesinde karakteristik kalıpları tanımlayan, kavramsal ve çok aşamalı modellerdir. Rekabet avantajı elde etmek veya elinde tutmak isteyen organizasyonlar açısından maliyetleri düşürme, kaliteyi artırma, tedarik süresini kısaltma gibi konularda yardımcı olurlar (De Bruin vd., 2005). Ayrıca olgunluk modelleri, örgütsel performansın iyileştirilmesinde de kullanılan yaygın araçlardır. Kıyaslama yapmanın yanı sıra örgütlerin güçlü ve zayıf yönlerini de ortaya çıkarırlar (Khoshgoftar vd., 2009).

Olgunluk modelleri, seçilen bir alanın olgunluğunu (yeterlilik, yetenek, gelişmişlik seviyesi gibi) bir dizi ölçüt temelinde değerlendirmek üzere tasarlanmışlardır (De Bruin vd., 2005). Firmaların Endüstri 4.0 olgunluk düzeylerini tespit etmek için kısa sürede çok sayıda olgunluk modeli oluşturulmuştur. Bu modellerden bazıları aşağıda verilmiştir.

\section{İlişkili Kurumsal Olgunluk Modeli (The Connected Enterprise Maturity Model)}

İlişkili kurumsal olgunluk modeli, 2013 yllında Rockwell Automation tarafından oluşturulmuştur. Model boyutları daha çok teknolojik hazırlık üzerinde durmaktadır. İlişkili olgunluk modelinin amacı daha akıllı OT/BT (Operasyon Teknoloji/Bilgi teknolojisi) ağının oluşturulmasıdır. Diğer bir değişle, işletmeler üzerinde OT ve BT teknolojilerini bir araya getirerek benzeri görülmemiş bir iş birliğinin oluşturulması amaçlanmaktadır (Rockwellautomation, 2012).

\section{Impuls Endüstri 4.0 Hazırlık Modeli (Impuls Industrie 4.0 Readiness)}

Model, Alman Mühendislik Federasyonu IMPULS Vakfı ve RWTH Aachen Teknik Üniversitesi Endüstriyel Yönetim Enstitüsü öğretim üyeleri tarafindan oluşturulmuştur. Hazırlık modeline göre, rekabet içerisinde olan şirketler, dijital dönüşüm sürecinde, hangi seviyede olduklarını ve Endüstri 4.0'ın potansiyelini tam anlamıla kullanıp kullanmadıklarını değerlendirmek zorundadırlar. Bu noktada hazırlık modeli endüstriyel şirketlerin Endüstri 4.0 yolunda gelişmişlik derecesini ölçmek için oluşturulmuştur (Lichtblau vd., 2015).

İmalat İşletmelerinin Endüstri 4.0 Hazırlığını ve Olgunluğunu Değerlendirmek İçin Bir Olgunluk Modeli (Maturity Model for Assessing Industry 4.0 Readiness and Maturity of Manufacturing Enterprises)

$\mathrm{Bu}$ model imalat işletmelerinin Endüstri 4.0 olgunluğunu değerlendirmek amacıyla kurgulanmıştır. Model hem bilimsel ve hem de pratik amaçları hedeflemektedir. Modelin bilimsel amacı, imalat işletmelerinin mevcut durumu ve potansiyel başarı faktörlerini ortaya çıkarmak için Endüstri 4.0 stratejileri hakkında güvenilir veri elde etmektir. Modelin pratik amacı ise, şirketlerin, Endüstri 4.0 olgunluk düzeylerinin ve mevcut stratejilerinin uygunluğunu titizlikle değerlendirmesini sağlamaktır (Schumacher vd., 2016). 


\section{Endüstri 4.0 Olgunlaşma Endeksi (Industrie 4.0 Maturity Index)}

Daha çok "dijitalleşme" olgusu üzerinde duran Endüstri 4.0 olgunlaşma endeksi, imalat işletmelerinin hangi seviyede olduklarını tespit etmelerine ve öğrenme açısından çevik bir şirket haline gelmelerine yardımcı olmayı amaçlamaktadır (Schuh vd., 2017).

\section{Endüstri 4.0 İçin Bir Değerlendirme Modelinin Geliştirilmesi: Endüstri 4.0 Olgunluk Modeli (Development of an Assessment Model for Industry 4.0: Industry 4.0-MM)}

$\mathrm{Bu}$ olgunluk modeli, kuruluşların sorunlu alanlarını, zayıflıklarını tespit etmeyi ve aynı zamanda Endüstri 4.0'a olan dönüşümün tutarlı bir şekilde gerçekleştirilebilmesi için kurum içinde uygulamaların gözlemlenmesini sağlamak üzere eksiksiz ve kapsamlı bir kılavuz oluşturmayı amaçlamaktadır.

\section{TÜBİTAK Dijital Olgunluk Modeli}

Dijital olgunluk modeli TUBİTAK- BİLGEM Yazılım Teknolojileri Araştırma Enstitüsü (YTE) tarafından 2017 yılında geliştirilmiştir. Olgunluk modelinin amacı kamu kurumları ve sundukları hizmetlerde dijital dönüşüm kapasitesi ve yetkinliğinin belirlenmesidir. Bu olgunluk modeli, ülke politikaları göz önünde bulundurulmak suretiyle, dijital dönüşüm konusundaki akademik çalışmalar ve diğer olgunluk modelleri incelenerek oluşturulmuştur (www.dijitalakademi.gov.tr, 2020).

\section{Enterprise) \\ Endüstri 4.0: Dijital Kuruluş Oluşturma (Industry 4.0: Building The Digital}

Dijital kuruluş oluşturma modeli, PWC (Price Water-house Coopers) şirketi tarafindan oluşturulan Endüstri 4.0'ı uygulamaya yönelik bir modeldir. Model, Endüstri 4.0 yeteneklerinin anahtarı olarak "dijitalleşme" stratejilerine odaklanmaktadır (Geissbauer vd., 2016).

\section{Endüstri 4.0 Stratejisi İçin Olgunluk ve Hazırlık Modeli (Maturity and Readiness Model for Industry 4.0 Strategy)}

Daha çok faaliyetlerini Endüstri 4.0 kavramı çerçevesinde dönüştürmeyi planlayan işletmeler için uygun olan bu model, firmaların ürünlerini, iş süreçlerini ve organizasyonlarını değerlendirmelerine ve olgunluk seviyelerini anlamalarına yardımcı olmayı amaçlamaktadır (Akdil, 2018).

\section{Benimseme Olgunluk Modeli (Adoption Maturity Model)}

$\mathrm{Bu}$ olgunluk modelinde, Endüstri 4.0'a geçiş yapan imalat şirketleri için bir değerlendirme çerçevesi geliştirilmiştir. Modelin amacı, Endüstri 4.0'1 uygulamaya başlamış olan bir kuruluşun olgunluk aşamalarını değerlendirmek ve Endüstri 4.0'ın benimsenmesine ilişkin sonuçları analiz etmektir. Bu model, Endüstri 4.0'a henüz adım atmamış kuruluşlar için değerlendirmede bulunamamaktadır (Scremin, 2018).

\section{Endüstri 4.0 Değerlendirme Aracı (An Industry 4.0 Readiness Assessment Tool) ${ }^{1}$}

$\mathrm{Bu}$ çalışmada da kullanılan bu olgunluk modeli, bir değerlendirme aracıdır ve çeşitli şirketlerin işbirliği ile Warwick Üniversitesi (The University of Warwick) akademisyenleri tarafından firmaların Endüstri 4.0 hazırlığını ölçmek için oluşturulmuştur. Modelin amacı Endüstri 4.0 hazırlığını değerlendirmek ve gelecekteki gerekliliklerin anlaşılmasını sağlamaktır. Model, 6 boyut, 37 alt boyut ve 4 değerlendirme seviyesinden oluşmaktadır. Olgunluk modeli başlangıç, orta düzey, uzman ve deneyimli olmak üzere dört değerlendirme seviyesinden oluşmaktadır

\footnotetext{
${ }^{1}$ Olgunluk modelinin incelenmesinde büyük ölçüde olgunluk modelinin tanıtımını içeren web tabanlı kaynaktan yararlanılmış̧ır. Kaynak: https://www.crimsonandco.com/wp-content/uploads/2017/10/Industry-4-readiness-assessmenttool-report-Oct-2017.pdf, erişim tarihi: 3 Ocak 2020
} 
(www.crimsonandco.com, 2020). Ayrıca model boyutları değerlendirilirken firmalar, alt boyutlar hakkında bir yeteneğe sahip değilseler "bu konu firmamızla ilgili değildir" ş̧eklinde bildirimde bulunabilmektedirler.

\section{Endüstri 4.0 Hazırlık Değerlendirme Aracı Olgunluk Modeli Boyutları}

Endüstri 4.0 Hazırlık Değerlendirme Aracı Olgunluk Modeline ilişkin boyut ve alt boyutlar Tablo 1'de verilmiştir.

Tablo 1. Bir Endüstri 4.0 Değerlendirme Aracı Boyut ve Alt Boyutları

\begin{tabular}{|c|c|c|}
\hline \multirow{8}{*}{ 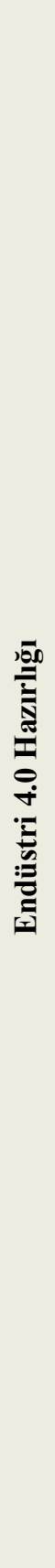 } & \multicolumn{2}{|r|}{ Bir Endüstri 4.0 Hazırlık Değerlendirme Aracı } \\
\hline & Boyutlar & \begin{tabular}{|c|} 
Alt Boyutlar \\
\end{tabular} \\
\hline & : & $\begin{array}{l}\text { - Ürün Kişiselleştirme } \\
\text { - Ürünün Dijital Özellikleri } \\
\text { • Veri Güdümlü Hizmetler } \\
\text { • Üründe Veri Kullanım Düzeyi } \\
\text { • Gelir Payı } \\
\end{array}$ \\
\hline & 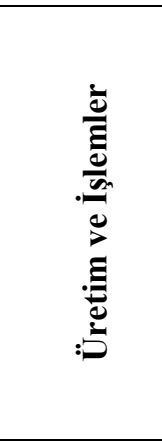 & $\begin{array}{l}\text { - Otomasyon } \\
\text { - Makine ve İşletim Sistemi Entegrasyonu (M2M) } \\
\text { - Endüstri 4.0 İçin Ekipman Hazırlığı } \\
\text { - Özerk Yönlendirilmiş İş Ekipmanları } \\
\text { - Kendi Kendine Optimizasyon Süreçleri } \\
\text { - Dijital Modelleme } \\
\text { - Veri Toplama Süreçleri } \\
\text { - Veri Kullanım Süreçleri } \\
\text { - Bulut Teknolojileri (Çözümleri) Kullanımı } \\
\text { - Veri ve BT (Bilişim Teknolojileri) }\end{array}$ \\
\hline & : & $\begin{array}{l}\text { - Endüstri 4.0 Stratejisini Uygulama Derecesi } \\
\text { - Endüstri 4.0 Ölçütleri } \\
\text { - Endüstri 4.0 Uyumu Konusundaki Yatırımlar } \\
\text { - Endüstri 4.0 İçin Çalışan Becerileri } \\
\text { - İşbirliği } \\
\text { - Liderlik } \\
\text { - Finansman }\end{array}$ \\
\hline & 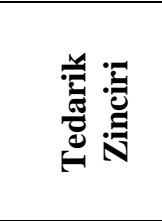 & $\begin{array}{l}\text { - Gerçek Zamanlı Veri Yönetimi Kullanarak Stok Kontrolü } \\
\text { - Tedarik Zinciri Entegrasyonu } \\
\text { - Tedarik Zinciri Görünürlüğü } \\
\text { - Tedarik Zinciri Esnekliği } \\
\text { - Tedarik Süresi }\end{array}$ \\
\hline & $\sum_{\substack{0 \\
\frac{\pi}{0}}}$ & $\begin{array}{l}\text { - Ürün ve Hizmetlerin Bulanıklaşması } \\
\text { • Veri Güdümlü Kararlar } \\
\text { - Gerçek Zamanlı İzleme } \\
\text { - Gerçek Zamanlı ve Otomatik bakım } \\
\text { - Entegre Pazarlama Kanalları } \\
\text { - BT Destekli İş Süreçleri }\end{array}$ \\
\hline & 焉 & $\begin{array}{l}\text { - Sözleşme Modelleri } \\
\text { - Riskler } \\
\text { - Veri Koruma Politikaları } \\
\text { - Fikri Mülkiyet Hakları }\end{array}$ \\
\hline
\end{tabular}

Kaynak: https://i4ready.co.uk/current-readiness/ - den uyarlanmıştır 


\section{Ürün ve Hizmetler}

Ürün ve hizmetler boyutunda ürünlerin kişiselleştirilebilme seviyesi oldukça önemlidir. Bunun yanı sıra ürünlerin Endüstri 4.0 açısından dijital özellik göstermesi ve elde edilen verilerin üründe kullanılma seviyesinin yüksek olması önemli kabul edilmektedir. Müşteri ile ilgili bilgiler dikkate alınarak veri güdümlü hizmetler sunulması ve veri güdümlü hizmetlerin firma geliri üzerinde etkili olmasının gerekliliği bu boyutta diğer önemli faktörler arasında yer almaktadır.

\section{Üretim ve İşlemler}

Üretim ve işlemler boyutu dört alana odaklanmakta ve boyutta bu yönde bir ölçüm yapılmaktadır. Bunlar;

- Teknoloji Entegrasyonu: otomasyon, makine ve işlemler sistemi entegrasyonu (M2M),

- Özerk İş Ekipmanları: kendi kendine optimize edilen süreçler, özerk kılavuzlu iş ekipmanları,

- Veri: operasyonel veri toplama, operasyonel veri kullanımı, bulut teknolojileri (çözümü) kullanımı, veri ve BT güvenliği,

- Kaynak Kabiliyeti: dijital modelleme ve Endüstri 4.0 için ekipman hazırlığıdır.

\section{Strateji ve Organizasyon}

Endüstri 4.0, firmaların iş stratejilerinde köklü bir değişiklik meydana getirmektedir. Firmalar, Endüstri 4.0 konusunda stratejik ve örgütsel uyum olmadan ilerleme kaydedememektedir. $\mathrm{Bu}$ nedenle Endüstri 4.0'ın benimsenmesi ve uygulanabilmesi için firmaların strateji ve organizasyonlarında Endüstri 4.0 olgusunun yer alması gerekmektedir. Lider ekibin farkındalığı, yatırımlar, çalışan becerileri ve departmanlar arasındaki yüksek düzeydeki işbirliği bu konuda hayati önem taşıyan unsurlar arasındadır.

\section{Tedarik Zinciri}

Endüstri 4.0 vizyonunun gerçekleştirilmesinde birçok iş süreci ve sistemin tamamen dijital hale gelmesi gerekmektedir. Tedarik zinciri de bu süreçlerden bir tanesidir. Bu noktada birçok lider konumdaki şirket, görünürlüğü artırmak ve farklı iş fonksiyonları arasındaki duvarları yıkmak için tedarik zincirinde ileri teknoloji uygulamalarına adım atmaktadır. Bu boyutta, tedarikçiler ve müşterilerle entegre bir tedarik zincirinin oluşturulması amaçlanmaktadır.

\section{İş Modeli}

Endüstri 4.0'ın sunduğu en önemli firsatlardan birisi, iş yapma biçimini yeniden yapılandırmaktır. Ayrıca bu yapılandırma işletmelere mevcut iş modellerini geliştirme fırsatı da vermektedir. Bu gelişim gerçek zamanlı izleme ve otomatik bakım, BT destekli iş süreçleri ve veri güdümlü kararların uygulamaya konulması ile desteklenmektedir.

\section{Yasal Hususlar}

Endüstri 4.0, üretim operasyonlarında, tedarik zincirlerinde ve iş modellerinde geniş kapsamlı bir değişim sürecidir. Firmaların, Endüstri 4.0'ın tüm potansiyelinden faydalanmaları ve iş uygulamalarını başarılı bir şekilde geliştirebilmeleri için yasal hususları göz önünde bulundurmaları gerekmektedir. Yasal hususlar boyutu sözleşme modelleri, yasal riskler, veri koruma politikaları ve fikri mülkiyet hakları gibi yasal gerekliliklere odaklanmaktadır.

\section{Araştırmanın Amacı ve Önemi}

Endüstri 4.0 gün geçtikçe ülkeler için bir zorunluluk ve milli bir politika haline gelmektedir. Orta gelir tuzağına yakalanmamak ve gelişmiş ülkeler sınıfına dâhil olmak adına Türk sanayisinin Endüstri 4.0 dönüşümünde farkındalık oluşturması ve bu konuda ileri sıralarda yer alması gerekmektedir. Bu noktada gerçekleştirilebilecek ilk çalışma, firmaların Endüstri 4.0 
hazırlık düzeylerinin tespitidir. $\mathrm{Bu}$ nedenle üniversite, firma, sivil toplum kuruluşu ve devlet kurumlarının uygun bir olgunluk modelini kullanarak, firmaların Endüstri 4.0 hazırlık seviyelerini ölçmeli ve bunları diğer ülke firmalarının seviyeleri ile karşılaştırmalıdırlar. Bunun yanında mutlaka bölge ve il düzeyinde hazırlık seviyelerinin tespit edilmesi gerekmektedir. Türkiye'de bu konuda sınırlı sayıda çalışma yapılmış olup, daha çok genel değerlendirmeleri içermektedir. Buradan hareketle araştırmanın amacı, Sivas ili organize sanayi bölgesinde faaliyet gösteren üretim işletmelerin Endüstri 4.0 hazırlığının hangi düzeyde olduğunu tespit etmektir. Böylelikle hem gelişmişlik sıralamasında dördüncü bölgede yer alan bir ilde faaliyet gösteren üretim işletmelerinin hazırlık düzeylerinin tespiti mümkün olabilecek hem de bölge ve ülke genelinde şirketler için bir öngörü oluşturulabilecektir.

\section{Araştırmanın Evreni, Örneklemi ve Yöntemi}

Araştırmada Sivas ili organize sanayi bölgesinde, farklı sektörlerde faaliyet gösteren (gıda, tekstil, mobilya, kimyasal ürünler, plastik ürünler, metal ve mermer, soğutma, savunma sanayi, endüstriyel soğutma, inşaat vb. alanlarında) 157 aktif, üretim yapan firmanın tamamına ulaşılmaya çalışılmış, ancak 50 firma ile çalışma gerçekleştirilebilmiştir. Çalışmada Warwick Üniversitesi'nin Endüstri 4.0 olgunluğunu ölçmek için geliştirilen "Endüstri 4.0 hazırlık değerlendirme aracı" isimli olgunluk modeli kullanılmıştır. Olgunluk modeli nicel araştırmalarda kullanılan veri toplama tekniklerinden olan anket tekniğine uygun olarak yeniden düzenlenmiş ve anket uygulaması, 30 Mayıs - 25 Haziran 2019 tarihleri arasında gerçekleştirilmiştir. Anket çalışması, işletmelerin yöneticileri fabrika müdürleri ya da bunların yönlendirdiği mühendisler ile yüz yüze görüşme şeklinde yapılmıştır. Gerekli ve sağlıklı bilgilerin alınabilemesi için çalışmanın amacı ve kapsamı katılımcılara belirtilmiş, anlaşılmayan sorular tek tek açıklanmış ve her bir anket tek tek doldurulmuştur. Elde edilen veriler, olgunluk ölçeğinin değerlendirilmesinde de kullanılan betimleyici istatistikler kullanılarak değerlendirilmiş ve elde edilen bulgular yorumlanmıştır.

\section{Olgunluk Modeli Seviyeleri ve Boyutlarına Ait Bulgular}

\section{Ürün ve Hizmetler Boyutuna Ait Bulgular}

Çalışmaya katılan firmaların, Ürün ve Hizmetler boyutunda, orta ile deneyimli seviye arasında yer aldıkları tespit edilmiştir. Bu boyutta firmalar, Şekil 1'de de görüleceği üzere en düşük seviyeyi Ürün Kişiselleştirilmesi alt boyutunda, en yüksek seviyeyi de Üründe Veri Kullanımı alt boyutunda yakalamışlardır.

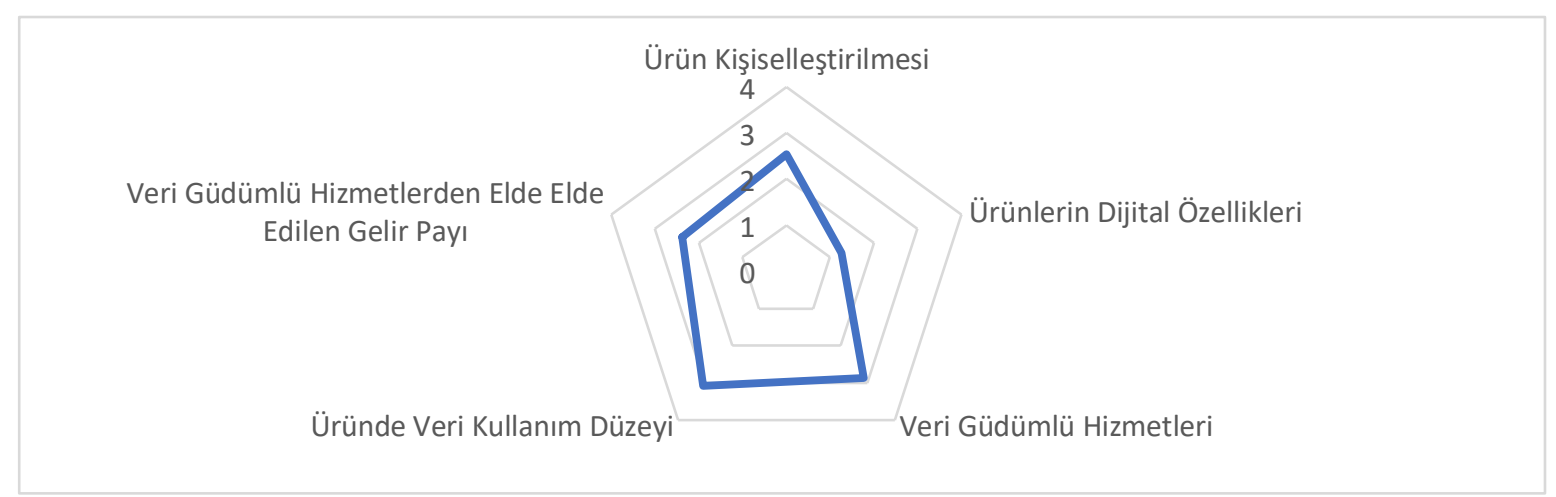

Şekil 1. Ürün ve Hizmetler Boyutuna Yönelik Genel Görünüm

\section{Üretim ve İşlemler Boyutuna Yönelik Bulgular}

Çalışmaya katılan firmaların, Üretim ve İşlemler boyutunda, başlangıç ile orta seviye arasında yer aldıkları tespit edilmiştir. Bu boyutta firmalar, Şekil 2'de de görüleceği üzere en düşük seviyeyi Endüstri 4.0 için Ekipman Hazırlığı ve Özerk yönlendirilmiş İş Ekipleri alt boyutlarında, en yüksek seviyeyi de Veri Kullanım Süreçleri alt boyutunda yakalamışlardır. 


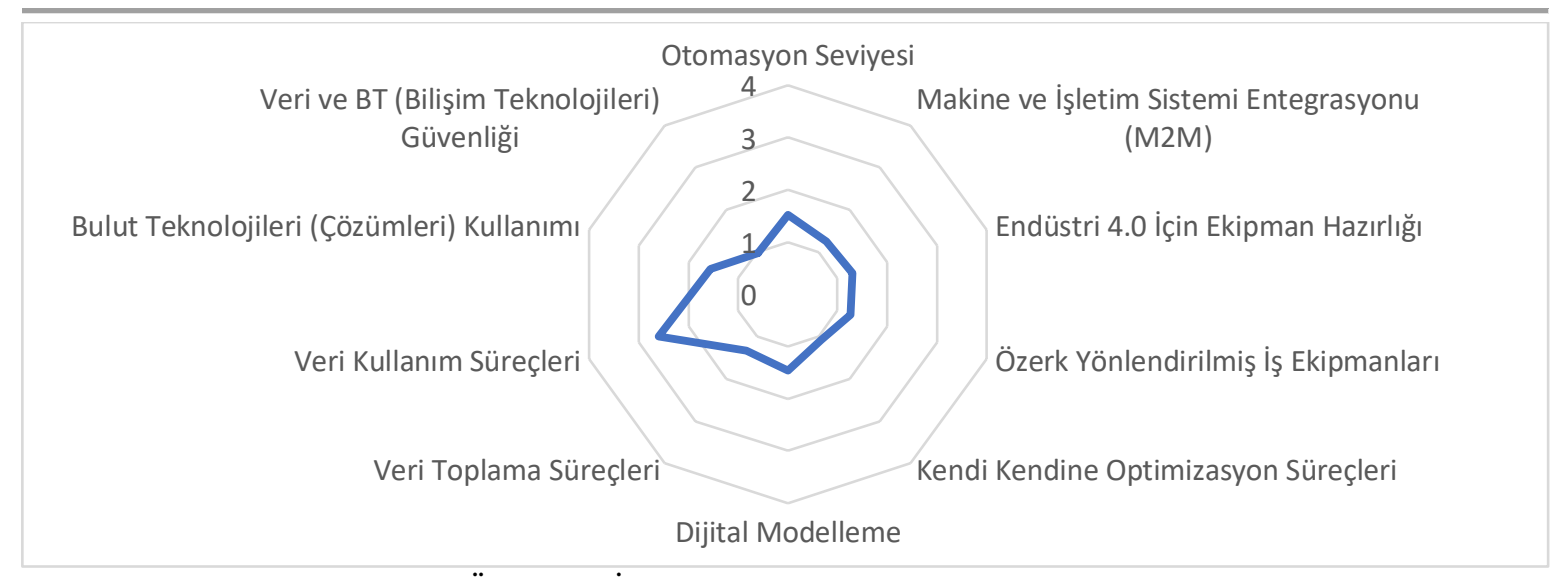

Şekil 2. Üretim ve İşlemler Boyutuna Yönelik Genel Görünüm

\section{Strateji ve Organizasyon Boyutuna Yönelik Bulgular}

Çalışmaya katılan firmaların, Strateji ve Organizasyon boyutunda, başlangıç ile orta seviye arasında yer aldıkları tespit edilmiştir. Bu boyutta firmalar Şekil 3 'te de görüleceği üzere en düşük seviyeyi Endüstri 4.0 Stratejisini Uygulama derecesi alt boyutunda, en yüksek seviyeyi de İşbirliği alt boyutunda yakalamışlardır.

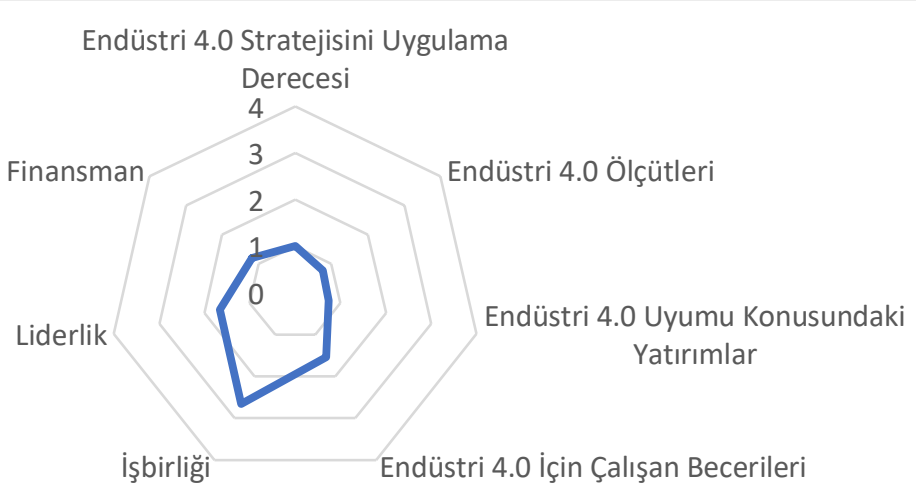

Şekil 3. Strateji ve Organizasyon Boyutuna Yönelik Genel Görünüm

\section{Tedarik Zinciri Boyutuna Yönelik Bulgular}

Çalışmaya katılan firmaların, Tedarik Zinciri Boyutunda, orta ile deneyimli seviye arasında yer aldıkları tespit edilmştir. Bu boyutta firmalar, Şekil 4'te de görüleceği üzere en düşük seviyeyi Tedarik Zinciri Görünürlüğü alt boyutunda, en yüksek seviyeyi de Tedarik Zinciri Esnekliği alt boyutunda yakalamışlardır.

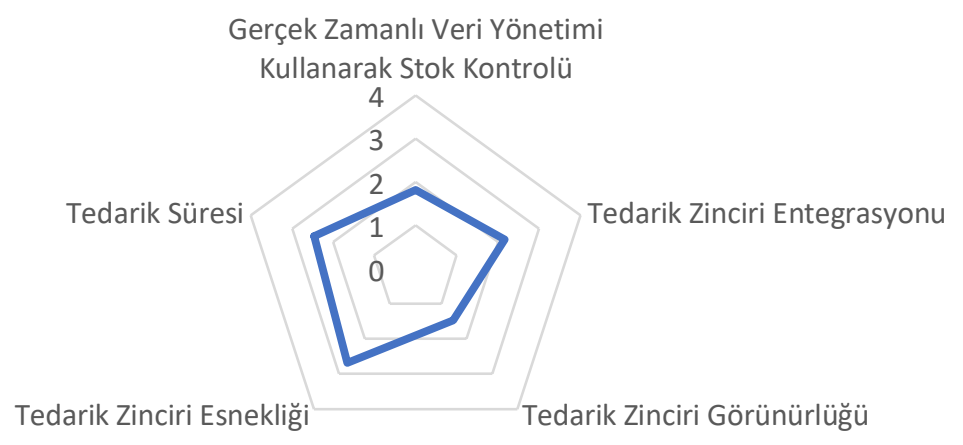

Şekil 4. Tedarik Zinciri Boyutuna Yönelik Genel Görünüm 


\section{İş Modeli Boyutuna Yönelik Bulgular}

Çalışmaya katılan firmaların, İş Modeli boyutunda, başlangıç ile orta seviye arasında yer aldıkları tespit edilmiştir. Bu boyutta firmalar, Şekil 5 'te de görüleceği üzere en düşük seviyeyi Gerçek Zamanlı ve Otomatik Bakım alt boyutlarında, en yüksek seviyeyi de Veri Güdümlü Kararlar alt boyutunda yakalamışlardır.

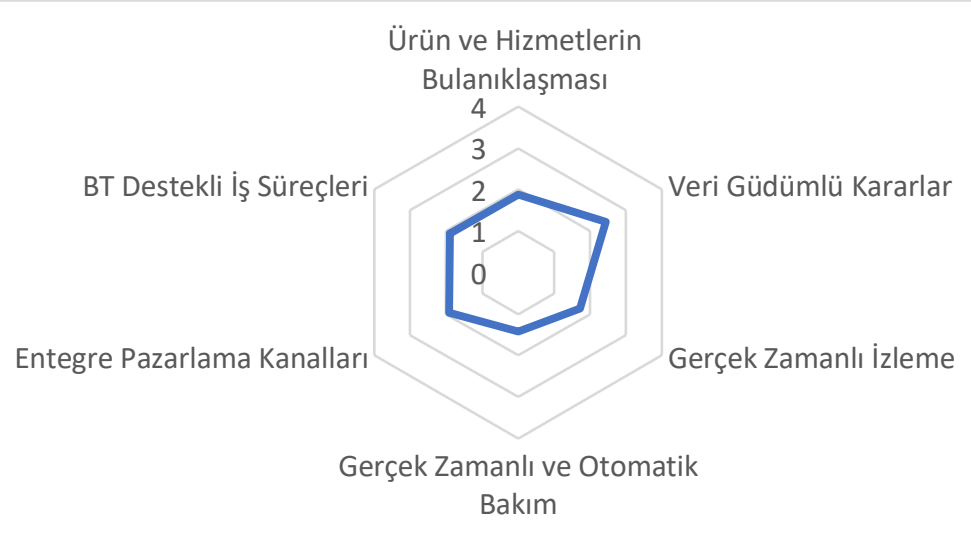

Şekil 5. İş Modeli Boyutuna Yönelik Genel Görünüm

\section{Yasal Hususlar Alt Boyutuna Yönelik Bulgular}

Çalışmaya katılan firmaların, Yasal Hususlar boyutunda, başlangıç ile orta seviye arasında yer aldıkları tespit edilmiştir. Bu boyutta firmalar, Şekil 6'da da görüleceği üzere en düşük seviyeyi Sözleşme Modelleri alt boyutunda, en yüksek seviyeyi de Fikri Mülkiyet Hakları alt boyutunda yakalamışlardır.

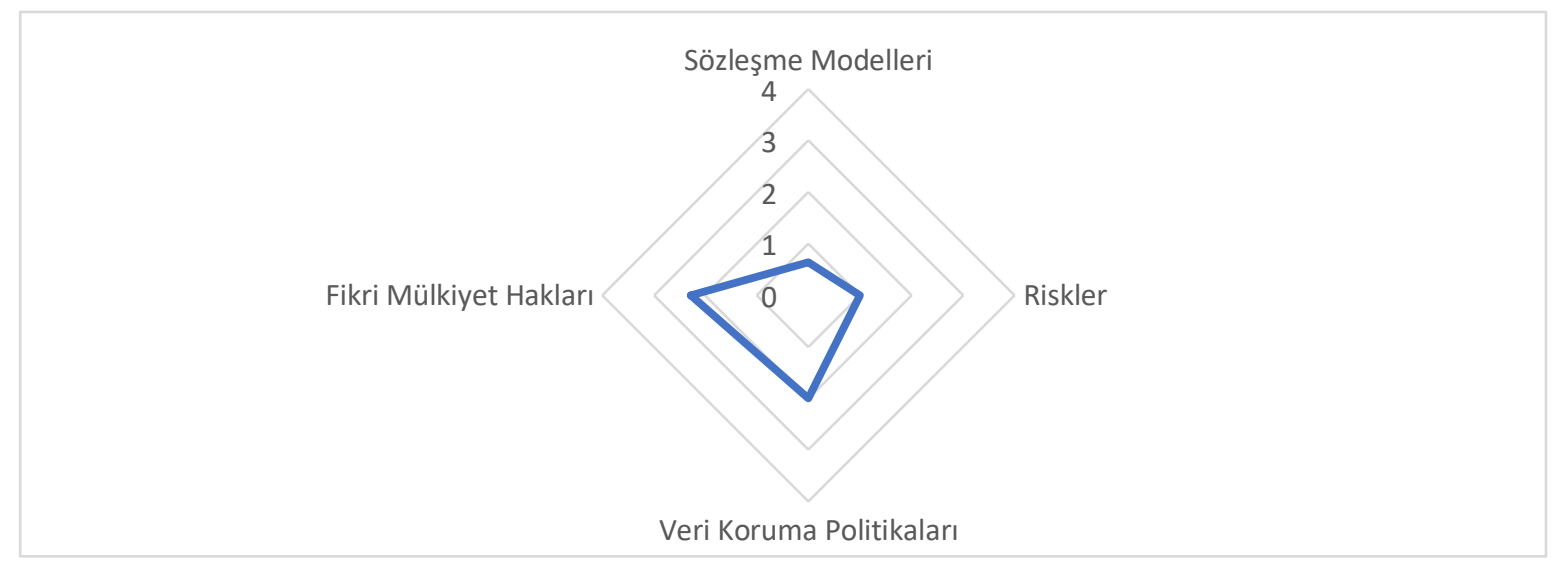

Şekil 6. Yasal Hususlar Boyutuna Yönelik Genel Görünüm

\section{Tüm Boyutları İçeren Genel Değerlendirme}

Olgunluk modelinde tüm boyutlar göz önüne alındığında, çalışmaya katılan firmaların Endüstri 4.0 hazırlığı konusunda genel anlamda orta seviyenin altında bir düzeyde yer aldıkları; yine firmaların en fazla Ürün ve Hizmetler boyutunda hazırlıklı oldukları; en az da Üretim ve İşlemler ile Strateji ve Organizasyon boyutunda hazırlıklı oldukları söylenebilir. 


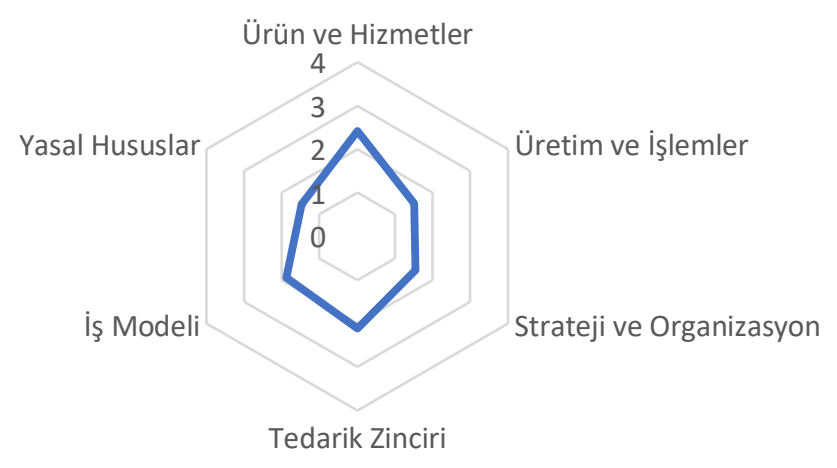

Şekil 7. Olgunluk Modelinin Boyutlarına Yönelik Genel Görünüm

\section{Hazırlık Boyutlarının Firma Faaliyet Süreleri Açısından Değerlendirilmesi}

Olgunluk modelin ana boyutları ve firmaların faaliyet yılları dikkate alındığında Şekil 8'de de görüleceği üzere 20 yıl ve daha fazla süredir faaliyet gösteren firmaların diğer firmalara kıyasla Endüstri 4.0 konusunda daha fazla hazırlıklı oldukları söylenebilir.

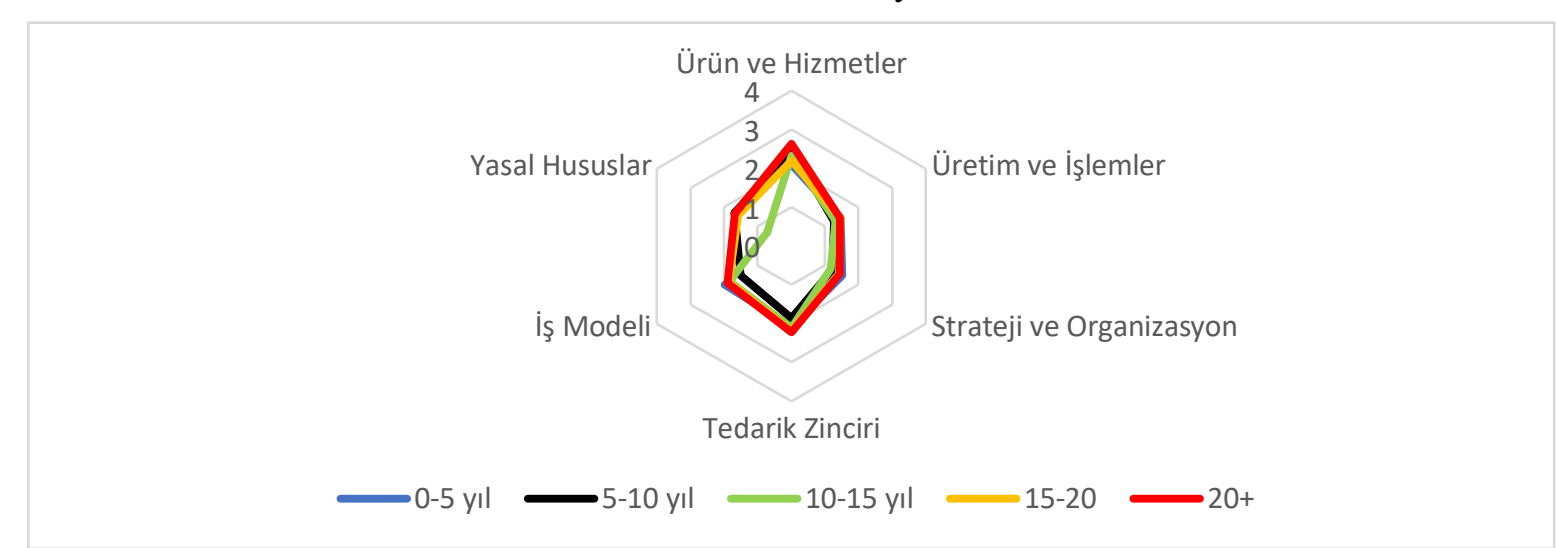

Şekil 8. Hazırlık Boyutlarının Firma Faaliyet Süreleri Açısından Genel Görünümü

\section{Değerlendirilmesi}

Hazırlık Boyutlarının Firmaların Faaliyet Gösterdikleri Sektör Açısından

Olgunluk modelin ana boyutları ve firmaların faaliyet gösterdikleri sektörler dikkate alındığında Şekil 9'da da görüleceği üzere metal sektöründe faaliyet gösteren firmaların, diğer firmalara kıyasla Endüstri 4.0 konusunda daha fazla hazırlıklı oldukları söylenebilir.

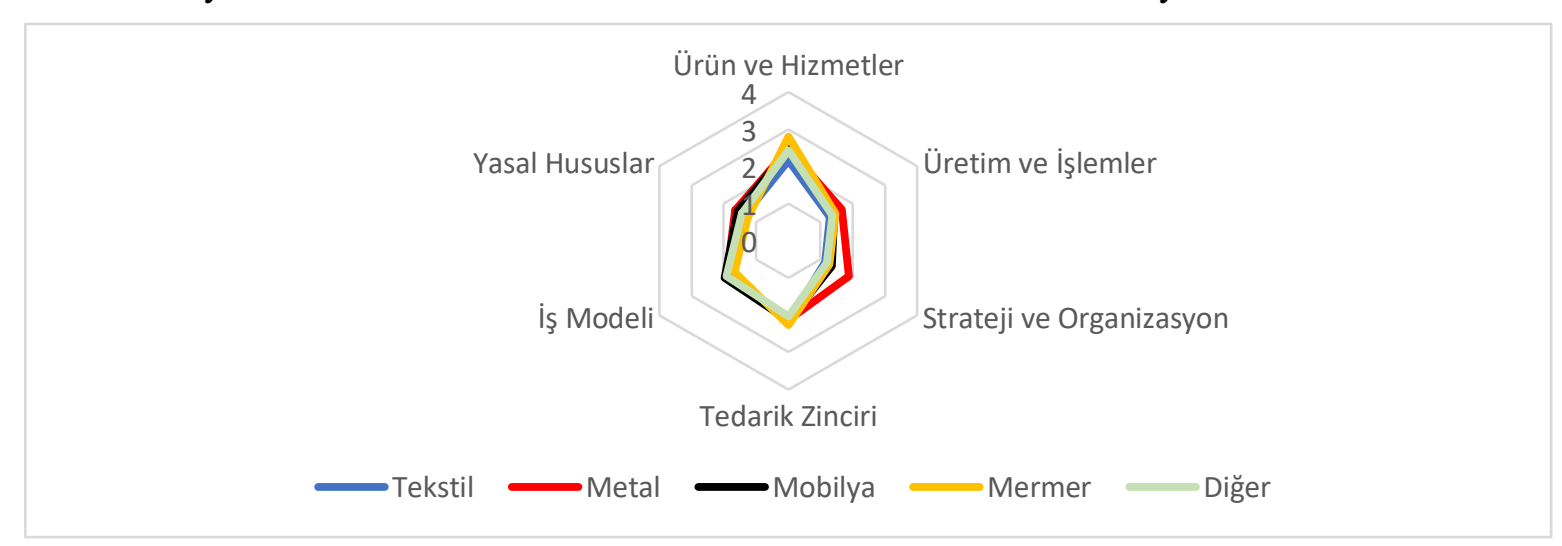

Şekil 9. Hazırlık Boyutlarının Firmaların Faaliyet Gösterdikleri Sektör Açısından Genel Görünümü 


\section{Hazırlık Boyutlarının İşletme Ölçekleri Açısından Değerlendirilmesi}

Olgunluk modelin ana boyutları ve işletme ölçekleri dikkate alındığında Şekil 10'da da görüleceği üzere büyük ölçekli firmaların diğer firmalara kıyasla Endüstri 4.0 konusunda daha fazla hazırlıklı oldukları söylenebilir.

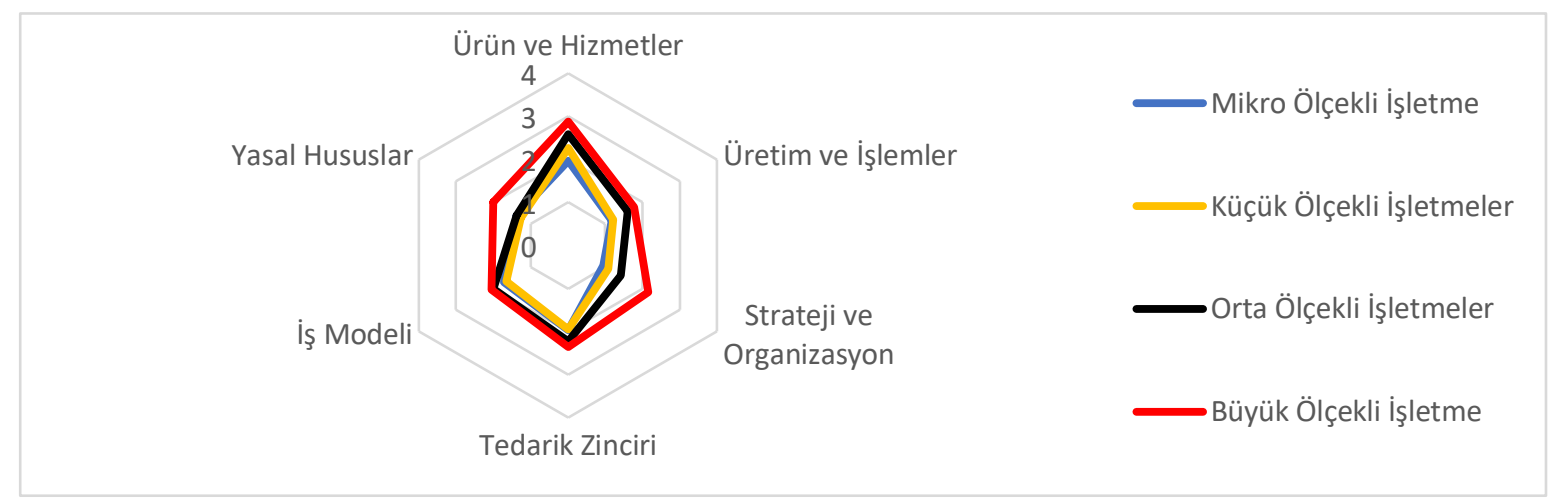

Şekil 10. Hazırlık Boyutlarının İşletme Ölçekleri Açısından Genel Görünümü

\section{Hazırlık Boyutlarının Firmaların Pazar Alanı Açısından Değerlendirilmesi}

Olgunluk modelin ana boyutları ve firmaların pazar alanları dikkate alındığında Şekil 11'de de görüleceği üzere uluslararası düzeyde faaliyet gösteren firmaların diğer firmalara kıyasla Endüstri 4.0 konusunda daha fazla hazırlıklı oldukları söylenebilir.

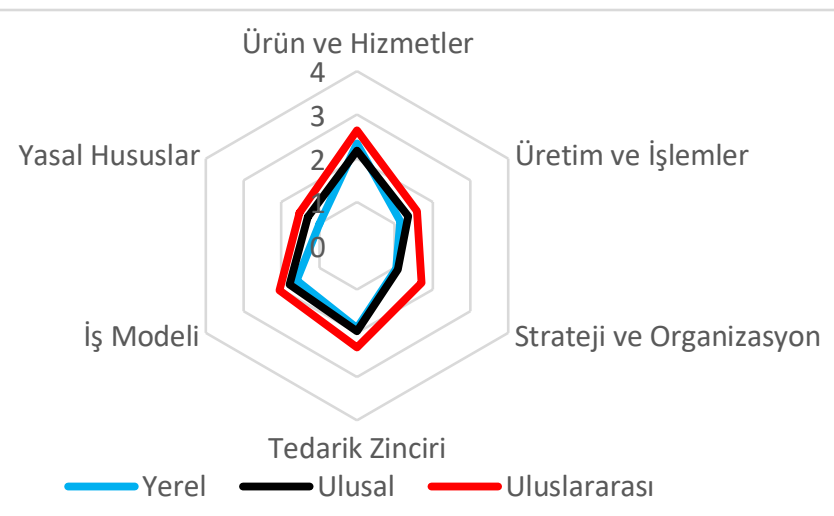

Şekil 11. Hazırlık Boyutlarının Firmaların Pazar Alanı Açısından Genel Görünümü

\section{Sonuç}

Rekabet dengelerini büyük ölçüde değiştirebilme potansiyeline sahip Endüstri 4.0'ın önemini kavrayan firmalar, stratejilerini yeni sanayi devrimi çerçevesinde şekillendirme, yatırımlarda bulunma, uygulamalarını ilerletme gayreti içine girmişlerdir.

Endüstri 4.0, sadece firmaların dikkate alması gereken bir değişim değil, bireyden toplumsal düzeye, firmalardan sektörlere, ekonomilere kadar her kesimin hazırlanması gereken bir devrimdir. Firma ve sektörler açısından yapılması gereken ilk iş bu devrime hazırlık düzeylerinin tespitidir. Ancak hazırlık düzeylerinin tespitinden sonra yol haritaları hazırlanabilir, kaynaklar bu konuya tahsis edilebilir ve uygulamaya geçilebilir.

Firmaların Endüstri 4.0 hazırlık düzeyleri hakkında fikir sahibi olmak, özelde Sivas ilinde üretim yapan firmaların Endüstri 4.0 olgunluk düzeylerini ve bu konudaki zayıf ve güçlü yönlerini tespit edebilmek amacıyla bu çalışma gerçekleştirilmiştir. 
Çalışmada diğerlerine göre daha detaylı ve güncel olması sebebi ile tercih edilen "Bir Endüstri 4.0 Hazırlık Değerlendirme Aracı" isimli olgunluk modelini kullanılmıştır ${ }^{2}$. Model yeniden düzenlenerek ankete dönüştürülmüş ve Sivas ili organize sanayi bölgesindeki imalat firmalarına uygulanmıştır. Elde edilen verilere betimleyici istatistikler uygulanarak, olgunluk modeli boyutlarının ve boyutların firmaların demografik verilerine göre değerlendirmeleri yapılmış ve bulgular yorumlanmıştır.

Çalışmaya katılan firmaların Üretim ve İşlemler, Strateji ve Organizasyon, İş Modeli, Yasal Hususlar boyutlarında, başlangıç ile orta seviye arasında Ürün ve Hizmetler ve Tedarik Zinciri boyutlarında ise orta düzey ile deneyimli seviyesi arasında yer aldıkları tespit edilmiştir.

Olgunluk modelinin tüm boyutları göz önüne alındığında, çalışmaya katılan firmaların Endüstri 4.0 hazırlığ 1 konusunda genel anlamda orta seviyenin altında bir düzeyde yer aldıkları; yine firmaların en fazla Ürün ve Hizmetler boyutunda hazırlıklı oldukları; en az ise Üretim ve İşlemler ile Strateji ve Organizasyon boyutunda hazırlıklı oldukları söylenebilir.

Olgunluk modelinin ana boyutları ve firmaların demografik özellikleri dikkate alındığında, metal sektöründe faaliyet gösterenlerin, 20 yıl ve daha fazla süredir faaliyette olanların, büyük ölçekli olanların ve uluslararası düzeyde faaliyet gösteren firmaların diğer firmalara kıyasla Endüstri 4.0 konusunda daha fazla hazırlıklı oldukları söylenebilir.

$\mathrm{Bu}$ sonuçlara göre çalışmaya katılan firmaların Endüstri 4.0 olgunluğu konusunda geneli itibariyle düşük seviyede yer aldıkları söylenebilir. Bu durumun nedenleri arasında firmaların halen geleneksel üretim yöntemlerini ssrarla terk etmek istememeleri, teknik açıdan yeterli ekipman ve çalışanlara (dijital becerilere sahip çalışanlar gibi) sahip olmamaları, organizasyon kültürü açısından Endüstri 4.0'a yatkın olmamaları, yeni iş modellerini benimsememeleri ve bu konuda yeterli yatırımda bulunmamaları gösterilebilir. Ayrıca lider ekibin Endüstri 4.0 kavramını geçici bir trend, kısa zamanda kâr getirmeyen, uzun ve maliyetli bir süreç olarak düşünmeleri de firmalar için diğer bir eksikliktir.

Endüstri 4.0 konusunda eksikliklerin giderilmesi ve firmaların Endüstri 4.0 olgunluğu hakkında önemli bir seviyeye gelebilmeleri için bazı çalışmalar yapılabilir. Bunlar, Endüstri 4.0 konusunda farkındalık oluşturulması, yapılan alt yapı ve hazırlıkların geliştirilmesi, devlet kanalıyla Bilişim Teknolojileri gibi alanlarda teknik destek sağlanması, yatırım ve teşviklerde bulunulması ve firmaların bir araya getirilerek ulusal bir platform üzerinde iş birliği içerisinde olmalarının sağlanması gibi çalışmalar olabilir.

\section{Kaynakça}

Akdil, K. Y., Ustundag, A., \& Cevikcan, E. (2018). Maturity and readiness model for industry 4.0 strategy. In Industry 4.0: Managing the digital transformation (pp. 61-94). Springer, Cham.

Alguliyev, R., Imamverdiyev, Y., \& Sukhostat, L. (2018). Cyber-physical systems and their security issues. Computers in Industry, 100, 212-223.

Bahrin, M. A. K., Othman, M. F., Azli, N. N., \& Talib, M. F. (2016). Industry 4.0: A review on industrial automation and robotic. Jurnal Teknologi, 78(6-13), 137-143.

Ceruti, A., Marzocca, P., Liverani, A., \& Bil, C. (2019). Maintenance in aeronautics in an Industry 4.0 context: The role of Augmented Reality and Additive Manufacturing. Journal of Computational Design and Engineering, 6(4), 516-526.

\footnotetext{
${ }^{2}$ Bazı çalışmalarda 'hazırlık' ve 'olgunluk' kavramları farklı değerlendirilmekle birlikte, bu model, 'hazırlık' ve 'olgunluğu', firmaların Endüstri 4.0 konusunda ne kadar yol aldıklarını ifade eden bir kavram olarak aynı anlamda kullanmaktadır.
} 
De Bruin, T., Freeze, R., Kaulkarni, U., \& Rosemann, M. (2005). Understanding the main phases of developing a maturity assessment model.

Ding, D., Han, Q. L., Xiang, Y., Ge, X., \& Zhang, X. M. (2018). A survey on security control and attack detection for industrial cyber-physical systems. Neurocomputing, 275, 1674-1683.

Frank, A. G., Dalenogare, L. S., \& Ayala, N. F. (2019). Industry 4.0 technologies: Implementation patterns in manufacturing companies. International Journal of Production Economics, 210, $15-26$.

Geissbauer, R., Vedso, J., \& Schrauf, S. (2016). Industry 4.0: Building the digital enterprise. Retrieved from PwC Website: https://www. pwc. com/gx/en/industries/industries-4.0/landing-page/industry-4.0-building-your-digitalenterprise-april-2016.pdf.

https://www.crimsonandco.com/wp-content/uploads/2017/10/Industry-4-readiness-assessmenttool-report-Oct-2017.pdf, erişim tarihi: 12 Şubat 2020

https://www.dijitalakademi.gov.tr/dijital-olgunluk, erişim tarihi: 12 Şubat 2020

ITU (2015). ITU-TX.1205: series X: data networks, open system communications and security: telecommunication security: overview of cybersecurity

ITU (2012). Series y: Global information infrastructure, internet protocol aspects and nextgeneration networks next generation networks-frameworks and functional architecture models. International Telecommunication Union, Geneva, Switzerland, Recommendation ITU-T Y, 2060.

Khoshgoftar, M., \& Osman, O. (2009, August). Comparison of maturity models. In 2009 2nd IEEE International Conference on Computer Science and Information Technology (pp. 297-301). IEEE.

Lichtblau, K., Stich, V., Bertenrath, R., Blum, M., Bleider, M., Millack, A., ... \& Schröter, M. (2015). IMPULS-industrie 4.0-readiness. Impuls-Stiftung des VDMA, Aachen-Köln.

Manyıka, James, et al. Big data: The next frontier for innovation, competition. and productivity. Technical report, McKinsey Global Institute, 2011.

Mell, P., \& Grance, T. (2011). The NIST definition of cloud computing.

Rockwellautomation: The Connected Enterprise Maturity Model. 12 (2014).

Rüßmann, M., Lorenz, M., Gerbert, P., Waldner, M., Justus, J., Engel, P., \& Harnisch, M. (2015). Industry 4.0: The future of productivity and growth in manufacturing industries. Boston Consulting Group, 9(1), 54-89.

Schuh, G., Anderl, R., Gausemeier, J., ten Hompel, M., \& Wahlster, W. (2017). Industrie 4.0 maturity index. Managing the digital transformation of companies. Munich: Herbert Utz.

Schumacher, A., Erol, S., \& Sihn, W. (2016). A maturity model for assessing Industry 4.0 readiness and maturity of manufacturing enterprises. Procedia Cirp, 52(1), 161-166.

Scremin, L., Armellini, F., Brun, A., Solar-Pelletier, L., \& Beaudry, C. (2018). Towards a framework for assessing the maturity of manufacturing companies in Industry 4.0 adoption. In Analyzing the Impacts of Industry 4.0 in Modern Business Environments (pp. 224-254). IGI Global.

Shafranek, R. T., Millik, S. C., Smith, P. T., Lee, C. U., Boydston, A. J., \& Nelson, A. (2019). Stimuli-responsive materials in additive manufacturing. Progress in Polymer Science. 
Sung, T. K. (2018). Industry 4.0: a Korea perspective. Technological forecasting and social change, 132, 40-45.

Schwab, K. (2016). The fourth industrial revolution, Mega-study Corporation, Seoul.

Zhu, W., Owen, C. B., Li, H., \& Lee, J. H. (2004). Personalized in-store e-commerce with the promopad: an augmented reality shopping assistant. Electronic Journal for E-commerce Tools and Applications, 1(3), 1-19. 